\title{
United Future Leaders Ambassadors: How do we engage young leaders in community service?
}

\author{
Kayla Sherman, M.S. \\ Assistant Director, United Future Leaders \\ Texas Tech University, Center for Adolescent Resiliency \\ Gloria Gonzales M.Ed. \\ Director, United Future Leaders \\ Texas Tech University, Center for Adolescent Resiliency \\ Sara. L. Dodd, Ph.D. \\ Director and Associate Professor \\ Texas Tech University, Center for Adolescent Resiliency \\ Erin Kostina-Ritchey, Ph.D. \\ Post-Doctoral Research Associate \\ Texas Tech University, Center for Adolescent Resiliency
}

\begin{abstract}
The United Future Leaders Ambassadors is a program developed out of the expressed desire of students to remain active in a youth leadership development program originally focusing on fifth and sixth grades. Our application brief discusses distinctions between youth development and youth leadership development, the evolutionary nature of our program and general/program specific lessons learned. Applying eight years of ongoing program evaluation and adaptation, authors provide suggestions for other leadership educators to incorporate active community service components to engage and retain adolescents long-term. Programming concerns such as developing and maintaining youth interest in service leadershipdevelopment, embracing technology for programming and research data, developing student and family "buy in," and integrating new youth into service programming from a variety of backgrounds are discussed.
\end{abstract}

\section{Issue Statement}

The importance of positive out-of-school developmental experiences in adolescence is well understood (Lauver \& Little, 2005), particularly those experiences that focus on developing youth capacity for leading self (Greiman \& Addington, 2008) and serving others (Webster, Bruce, \& Hoover, 2006). However, retaining youth engagement and interest in long-term leadership development programming and active community service is a challenging, timeconsuming process for youth professionals. Being able to commit sufficient resources to critical ongoing program evaluation and adaptation is a luxury not afforded to many educational practitioners. 
The purpose of this paper is to share with other youth leadership organizations the benefits of extending an after-school leadership program for younger adolescents to include explicitly youth-driven service leadership opportunities throughout the years of active program participation and beyond. Hopefully by sharing the processes, strategies, and lessons learned over an 8-year period will save time and resources for other youth leadership organizations seeking to introduce or strengthen their leadership-in-action program components.

Background/Context. The United Future Leaders (UFL) program was created through a collaboration of a corporate sponsor, private charitable foundation, area schools, and a large public university. From this partnership, a two-year after-school program was created to proactively support students in early adolescence (ages 11-12) by developing identities and competencies associated with healthy self-leadership that are essential for effective leadership of others. Formal UFL programming cohort starts at the beginning of the fifth grade year and concludes during the sixth grade year. Within two years of its 2007 pilot, UFL parents and participants requested ongoing programming to support the children's desire to stay involved in leadership activities as they progressed through secondary school. Parents voiced a concern that upon entering secondary school, students were encouraged/required to select a limited number of activities rather than continue engagement in multiple programs.

Some extracurricular programs target specific activities and/or demographic groups. For example, Boy Scouts of America (Polson, Kim, Jang, Johnson, \& Smith, 2013) offers many service-oriented activities primarily for males while the National Charity League (National Charity League, 2016) supports philanthropy among mothers and daughters. Although these organizations and others like them have recognized social value, UFL participants and families sought opportunities for deeper learning and service that would involve like-minded youth from diverse backgrounds. UFL thus expanded its original mission from a weekly after-school program to a broader platform that supports youth who aspire to be lifelong leaders. Since establishing an explicit service-leadership component UFL has continued to adapt resources to best serve students' developmental needs and preferred program engagement.

\section{Review of Related Scholarship}

Youth practitioners could be forgiven for thinking the terms youth development and youth leadership are virtually synonymous (Greiman \& Addington, 2008). A great deal of the applied research related to youth development that we have comes from studies of individuals who participate in youth leadership programs (e.g., Lerner et al., 2005; Gestsdóttir \& Lerner, 2007; Jelicic et al., 2007; Klau, 2006; Li, Bebiroglu, Phelps, \& Lerner, 2009; Mueller, et al., 2011; Schmid et al., 2011). As Kress (2006) noted:

It is easy to become convinced that, whether we are developing leaders or developing youth, intentions and actions should be the same because both have many overlapping aims and the differences may be revealed only when we focus at more than a superficial level (p. 46).

Edelman et al. (2004) assert that youth leadership ability is "a distinct area of youth development with a primary focus on mastery of certain competencies necessary for effective leadership, 
including responsibility, teamwork, and vision" (p. 4). The Positive Youth Development(PYD) model seems to support this notion (Lerner, et al., 2013). A full discussion of the PYD model is beyond the scope of this brief but in summary, the model is derived from relational and developmental systems theory (see Overton, 2010) yet congruent with concepts present in the literature of adult leadership (e.g., Murphy \& Johnson, 2011). PYD posits that positive youth development occurs when an adolescent's individual strengths and ecological assets (family, peers, school, community, and so on) align with or influence each other in ways that promote thriving (Theokas \& Lerner, 2006; Gestsdottir, et al., 2011). PYD is said to be present when youth manifest the 5 C's - Competence, Confidence, Connection, Character, and Caring. These five outcomes lead the individual on a further developmental trajectory toward a 6 th $\mathrm{C}$, Contribution (Lerner, et al., 2005).

The design and development of the original UFL program as well as its serviceleadership spinoff is closely informed by the PYD model as well as Self-Determination Theory (SDT) (Deci \& Ryan, 2000). SDT models the relationship between individual motivation and self-regulating behavior, with motivation defined as "psychological energy directed at a particular goal" (Patrick \& Williams, 2012, p. 2). Multiple studies have utilized SDT to understand adolescent motivation to adopt health-related behaviors (e.g., Power, Ullrich-French, Steele, Daratha, \& Bindler, 2011; Thøgersen-Ntoumani, Ntoumanis, \& Nikitaras, 2010). SDT maps a path moving from external regulation (behaving to get a reward or avoid something negative) to integrated regulation (behaving in concert with internalized goals and values) (Patrick \& Williams, 2012). SDT identifies three psychological needs that must be met if selfdetermined or self-regulated behavior is to be optimized and sustain positive development - the need for autonomy, the need for competence, and the need for relatedness (Deci \& Ryan, 2000).

The overarching goal of UFL programming is to provide learning experiences that meet individual developmental needs (such as emotional safety, belonging, and identity) but to do so through facilitated learning that builds students' sense of mastery (competence), provides them with opportunity and space to apply learning for themselves (autonomy), and to do so with the support of caring, invested adults (relatedness). UFL curricular themes also emphasize empathy and awareness of how personal expressions of ethics and civility affect others. The ultimate goal is to actively support and encourage early adolescents to embrace the Ambassador programming mantra "the first person I will lead is me" and to use it to build a portfolio of service leader abilities. Our approach is consistent with research that suggests experiential pedagogies can develop leadership among adolescents (Jones, 2009), and that cultivating leader competencies in adolescence is important and desirable (Hancock, Dyk, \& Jones, 2012).

\section{Application Description}

Program Development. In 2013 the service-leadership component of the UFL program received its own title - "UFL Ambassadors". All current UFL participants and program alumni were invited to renew their commitment to leadership development and to engage with the program on a new level. Participation expanded to include organized service activities (two per semester), student training workshops and annual leadership development conferences for students and their families. In addition an online service log was developed for students to record their individual service activities throughout the year. The 'ambassador' format facilitates 
expanded service leadership participation beyond the students who were directly involved in UFL programs in 5-6 grades. The only requirements to participate with UFL Ambassadors are a sincere interest in honing leadership abilities, commitment to community service, and completion of a service framework training. The program now includes $400+$ active participants in grades 6 through college juniors.

In the ongoing refinement and evaluation of the UFL Ambassador program we have identified a few barriers to engagement faced by our students. Our strategies to address these barriers may be helpful to other practitioners because they are barriers common to most adolescents. Our program goals are to ensure that students' leadership development needs are addressed, but their needs are not all that different from students in other programs. Specifically:

- Students are busy - Secondary students often struggle to balance extracurricular activities and academic demands (Fredricks, 2012; Melman, Little, \& Akin-Little, 2007; Strom, Strom, \& Sindel-Arrington, 2016). We strive to create service activities that promote consistent engagement without overwhelming students with requirements that may discourage involvement.

- Activities should engage - The Ambassador program brings together youth from a variety of age groups, schools, communities and backgrounds, thus activities need to have broad appeal. We offer events for high school Ambassadors to mentor middle school peers, encourage active engagement, and allow students to interact with diverse populations and community needs. These opportunities expand each individual's world-view, understanding, and empathy (Ginwright, Noguera, \& Cammarota, 2006; Richards-Schuster \& Dobbie, 2011; Sherrod, Flanagan, \& Youniss, 2002; Simmons, L. \& Harding, S., 2011).

- Students need to feel connected - Connectivity is important to engage a large group of young people (Akos, 2006; Karcher, 2008; Lekies, 2009; Oliver, Collin, Burns, \& Nicholas, 2006). We considered how to help students feel connected to theirfellow UFL Ambassadors as well as to the program itself. Offering teambuilding opportunities and other ways for students to share their individual activities, challenges, and successes is important.

- Vocabulary must be consistent - With students entering the program at different grade levels (some enter in the 5th grade while others begin in high school), all students need a common understanding of the UFL program mission and philosophy (Schultheiss \& Pennington, 2009; Sheffield, 2011). The S.M.I.L.E. Service Framework (described in greater detail below) is a step-by-step process for planning, organizing and evaluating any service project. The framework provides the foundational knowledge all students need to successfully engage in activities and to promote program identity among members and key stakeholders. S.M.I.L.E. is incorporated into all program aspects including training, the online service logs, and teambuilding as well as our annual service celebration.

Activities Implemented. In order to sustain engagement among participants, we continuously plan new leadership and service opportunities. However, we also believe it is essential to maintain long-term relationships with community partners and to allow students opportunities to continue their connection, understanding and involvement with the organizations 
and populations they serve. Program activities are constantly evolving, Table 1 is a snapshot of the mission in action.

Table 1

UFL Ambassador Mission in Action 2008-2016

\begin{tabular}{|c|c|c|c|c|}
\hline Activity & Timeline & Who/What & Activity/Service Details & $\begin{array}{c}\text { Outcomes (planned } \\
\text { assessments)* }\end{array}$ \\
\hline $\begin{array}{l}\text { Leadership } \\
\text { Conference }\end{array}$ & $\begin{array}{l}\text { New Event- } \\
2016\end{array}$ & $\begin{array}{l}\text { UFL } \\
\text { Ambassadors } \\
\text { (grades 6-12) } \\
\text { and parents }\end{array}$ & $\begin{array}{l}\text { - Program registration } \\
\text { - Parent Sessions: } \\
\text { Program overview \& } \\
\text { resources } \\
\text { - Student Sessions: } \\
\text { Service log practice; } \\
\text { leadership \& } \\
\text { teambuilding activities. }\end{array}$ & $\begin{array}{l}\text { Increased knowledge of } \\
\text { service and self- } \\
\text { leadership components } \\
\text { (program evaluation } \\
\text { and attendance) }\end{array}$ \\
\hline $\begin{array}{l}\text { Winter } \\
\text { Service } \\
\text { Event }\end{array}$ & $\begin{array}{c}\text { February } \\
\text { New Event- } \\
2016 \\
\text { (6-year } \\
\text { partnership) }\end{array}$ & $\begin{array}{l}\text { Ronald McDonald } \\
\text { House Charities; } \\
\text { (RHMC) families } \\
\text { of critically ill } \\
\text { children }\end{array}$ & $\begin{array}{l}\text { - Ambassadors tour the } \\
\text { local Ronald McDonald } \\
\text { House; prepare a meal } \\
\text { for the families using the } \\
\text { RMHC kitchen } \\
\text { facilities. }\end{array}$ & $\begin{array}{l}\text { Integration of new } \\
\text { members following the } \\
\text { Leadership Conference } \\
\text { (attendance; service } \\
\text { logs) }\end{array}$ \\
\hline $\begin{array}{l}\text { Spring } \\
\text { Service } \\
\text { Event }\end{array}$ & $\begin{array}{c}\text { May } \\
\text { (6-year } \\
\text { partnership) }\end{array}$ & $\begin{array}{l}\text { Special } \\
\text { Olympics } \\
\text { Spring Games; } \\
\text { individuals with } \\
\text { special needs }\end{array}$ & $\begin{array}{l}\text { - Ambassadors host a face } \\
\text { painting booth; serve as } \\
\text { event runners, support } \\
\text { athletes in their events, } \\
\text { and assist with awards }\end{array}$ & $\begin{array}{l}\text { Increased student } \\
\text { engagement in outdoor } \\
\text { environment } \\
(\text { attendance; service } \\
\text { logs) }\end{array}$ \\
\hline $\begin{array}{l}\text { Service } \\
\text { Summit }\end{array}$ & $\begin{array}{c}\text { June } \\
\text { annual event } \\
\text { - developed } \\
2013\end{array}$ & $\begin{array}{l}\text { UFL } \\
\text { Ambassadors } \\
\text { (grades 6-12) } \\
\text { and parents }\end{array}$ & $\begin{array}{l}\text { - Training in S.M.I.L.E. } \\
\text { service framework and } \\
\text { service log; interactive } \\
\text { teambuilding activities } \\
\text { - Recognition ceremony }\end{array}$ & $\begin{array}{l}\text { Increased } \\
\text { understanding \& } \\
\text { application of service } \\
\text { leadership } \\
\text { (attendance, program } \\
\text { evaluation, service } \\
\text { logs) }\end{array}$ \\
\hline $\begin{array}{l}\text { Back-To- } \\
\text { School } \\
\text { Service } \\
\text { Event }\end{array}$ & $\begin{array}{c}\text { August } \\
\text { (4-year } \\
\text { partnership) }\end{array}$ & $\begin{array}{l}\text { Regional facility } \\
\text { for long-term } \\
\text { foster care for } \\
\text { children }\end{array}$ & $\begin{array}{l}\text { - Ambassadors gather } \\
\text { donated backpacks and } \\
\text { school supplies at TTU } \\
\text { parking booth } \\
\text { - Partner collects } \\
\text { donations }\end{array}$ & $\begin{array}{l}\text { Enhanced application } \\
\text { (attendance, donation } \\
\text { inventory, service logs; } \\
\text { partner feedback) }\end{array}$ \\
\hline $\begin{array}{c}\text { Fall Service } \\
\text { Event }\end{array}$ & $\begin{array}{c}\text { October } \\
\text { (2-year } \\
\text { partnership) }\end{array}$ & $\begin{array}{l}\text { Faith-based } \\
\text { neighborhood } \\
\text { community } \\
\text { resource center } \\
\text { targeting } \\
\text { families in need }\end{array}$ & $\begin{array}{l}\text { - Ambassadors prepare } \\
\text { and distribute meal } \\
\text { packages for } \\
\text { neighborhood families. }\end{array}$ & $\begin{array}{l}\text { Increased } \\
\text { understanding and } \\
\text { empathy for poor } \\
\text { families } \\
\text { (attendance, service } \\
\text { logs; parent feedback) }\end{array}$ \\
\hline
\end{tabular}




\begin{tabular}{|c|c|c|c|c|}
\hline $\begin{array}{l}\text { 6th Grade } \\
\text { Celebration } \\
\text { Banquet }\end{array}$ & $\begin{array}{l}\text { December } \\
\text { annual event } \\
\text { - developed } \\
2008\end{array}$ & $\begin{array}{l}\text { UFL staff; youth } \\
\text { participants } \\
\text { (grade 6) and } \\
\text { families }\end{array}$ & $\begin{array}{l}\text { - UFL staff recognize } \\
\text { two-year commitment of } \\
6^{\text {th }} \text { grade participants } \\
\text { - Students invited to } \\
\text { continue as } \\
\text { Ambassadors } \\
\end{array}$ & $\begin{array}{l}\text { Promotion to } \\
\text { Ambassador; increased } \\
\text { commitment among } \\
\text { parents/ } \\
\text { students/admin. } \\
\text { (attendance) }\end{array}$ \\
\hline $\begin{array}{l}\text { Holiday } \\
\text { Service } \\
\text { Event }\end{array}$ & $\begin{array}{c}\text { (New Event - } \\
\text { 2015) }\end{array}$ & $\begin{array}{l}\text { Assisted living } \\
\text { center for the } \\
\text { elderly }\end{array}$ & $\begin{array}{l}\text { - Ambassadors deliver } \\
\text { treats and play games } \\
\text { with residents; residents } \\
\text { share leadership and } \\
\text { service experiences }\end{array}$ & $\begin{array}{l}\text { New Ambassadors } \\
\text { engaged } \\
\text { (attendance, service } \\
\text { logs) }\end{array}$ \\
\hline
\end{tabular}

*items in ( ) indicate method of assessment

Service Log. The service log component of the UFL Ambassador program provides a framework for students to better understand service-learning. Youth often participate in school and/or community-based organizations that require service activity. Although such a requirement is intended to encourage youth to lead and serve in their communities, sometimes the purpose of such activities gets lost in the logistics.

We define service as "I help others, expecting nothing in return" (United Future Leaders, 2016). Our goal is for students to internalize a desire to give their time and talent to serve others without the expectation of tangible benefits. The service log format began in order to provide training to further explain organization missions and community needs, as well as asking students to describe and reflect upon their experiences. The hope is that this will increase students' intrinsic motivation to serve.

Using survey software (Qualtrics, 2015) we created an online recording tool for students to record and report their service activity (useful for college admissions and scholarship applications). Qualtrics is a user-friendly and cost-effective method to collect information for educational purposes. The software is provided and supported through our university and is highly intuitive for users with limited technology knowledge and skills. The online record acts as a service diary or log that also can be used for research purposes (formal consent/assent is obtained in accordance with human subjects' policies at our partner university). The online service log guides students in describing their specific service activities by answering various multiple response, Likert-type scales, and open-ended items. UFL Ambassadors are encouraged to utilize the service training they receive based on the S.M.I.L.E. framework - an essential component of the online service log that guides students in defining each step in the planning and execution processes. Each letter of the S.M.I.L.E. acronym asks the student to answer specific questions related to the service activity, including:

- S - Situation - "What is the need for service?"

- M - Mission - "What is the goal of the service?"

- I - Ideas - "What can be done?"

- L - Logistics - "How will it be done?", "What are the details?" 


\section{- E - Execution - "What needs to be completed?", "What is your plan B?"}

The S.M.I.L.E. Framework emphasizes the previously stated program goal for students to understand the mission and purpose of their service involvement as well as the details that must be considered to make the activity successful. S.M.I.L.E. encourages students to actively reflect upon their experience and its effect on the community and/or organization, which enhances the students' feeling that their service directly impacts people in need. In addition students complete survey items including the type of service (individual, small-scale, or large-scale), frequency of involvement, roles fulfilled during the activity, level of involvement in activity components (e.g., planning, implementation, evaluation), whether friends or family members served alongside them, and evaluation of impact and interest in future involvement. Completing the service logs encourages students to develop reflective leadership skills (Roberts, 2008).

\section{Discussion of Outcomes}

As the UFL Ambassador program evolves, three potentially noteworthy outcomes (based on program impact with students, the community at large and the program itself) have been noted and perhaps may be beneficial to other educational practitioners. The first outcome relates to the many opportunities provided for young leaders to serve diverse populations/needs. Service activities are reviewed on an annual basis to ensure students are exposed to various societal concerns and have the opportunity to interact with different groups of people. In addition, Ambassadors are offered opportunities for direct service (e.g., Special Olympics Spring Games) as well as indirect service (e.g., gathering school supplies for a regionalchildren's home) (Duerden \& Witt, 2010; Kaye, 2010; Sherrod, 2016). In each of these experiences, students gain real-world understanding of how leadership and service impact the lives of those in need. A range of different service opportunities allows youth to be empowered to practice leadership competencies.

A second outcome of the UFL Ambassador program is the consistent use of the online service log system. With over 2,500 service hours logged in 2013-2015, it appears the Ambassadors are recognizing the benefits of maintaining a consistent log of individual and program-related service work. Additionally, the service log strengthens accountability for both the program and its participants (Root, Callahan, \& Billig, 2005). Information gained through service logs allows our staff and researchers to monitor trends in student service engagement (e.g. times of year, specific organizations, repetitive involvement) and ensures that we establish partnerships and plan activities that are responsive to student needs. The service log also encourages students to rate their level of interest and impact, and to suggest alternative plans which in turn is also a useful evaluation of activities provided by the Ambassador program. For students, the online service log provides a means of connecting with us between scheduled program-related activities. The service log adds a level of accountability for students to demonstrate their learning and service-leadership involvement within other programs, groups and/or individually (Wilczenski \& Cook, 2009).

Perhaps the most rewarding outcome we have observed is the long-term engagement of students. Of the 26 students who participated in the 2007 pilot of the original after-school program as 5th graders, 17 attended a Senior Pinning Ceremony to celebrate their seven-year 
dedication when they graduated from high school in 2014. Despite the fact that several of these students have matriculated to universities all across the state and nation, UFL alumni consistently return to participate in weekend service activities or to become volunteer facilitators in UFL after-school or summer activities. Several UFL alumni have promoted the program to family members and friends, making involvement in the program a "rite of passage" for many. We believe that the UFL Ambassador program has successfully maintained engagement with a majority of its original participants because we do not overwhelm the students with stringent participation criteria or an expectation that our events take precedence over other interests.

\section{Practitioner Reflections}

The UFL Ambassador program is gaining momentum among youth and families served. The organized and streamlined process is inviting to participants because it supports their individual leadership endeavors while promoting positive relationship-building among peers and communities. We try to embody "a living, breathing program", constantly evolving to meet the needs of students, families, communities, and other stakeholders (Mathews, Hempel, \& Howell, 2010). Recent updates to the online service log system have increased its accessibility and easeof-use for students. In 2016, based on student responses, the online service log moved towards an adapted format to allow for more personalized assessment and to offer "mobile-friendly" access (Ling \& Bertel, 2013). Through continued adoption of new technology and innovative ideas, our goal is to provide a program that will enhance and enrich the experience of developing leaders.

As our UFL Ambassadors become more involved in the program and experience the benefits of participation, increasingly they invite non-registered friends and family members to serve alongside them at sponsored events. While this level of promotion is encouraged, and aligns with our mission to "take leadership out to the world", we have had to consider how best to welcome these visitors, make them feel a part of the group, and motivate them to become official members. To leverage this natural opportunity to recruit, we are exploring options to collect visitors' contact information as well as a short reflection of their first experience with the program. Our staff can then follow up with a formal invitation tojoin.

In our experience, the UFL Ambassador program is unique in that it does not preclude students from participating in other programs. Students have a variety of options of how to spend their time away from school, and most participate in multiple arenas. We choose to use the Ambassador program to support students in all of their activities (school or community leadership programs, religious organizations etc.). That is, we want to encourage them to promote leadership and service among their peers wherever they participate. We believe this level of support fosters a deeper sense of integration and connection for our students, resulting in the mission and philosophy becoming an integral part of their identities (Crocetti, Jahromi, \& Meeus, 2012; Riggs, Bohnert, Guzman, \& Davidson, 2010). Students' engagement and willingness to promote program concepts within their personal lives actively demonstrates the title, "Ambassador." 


\section{Recommendations}

As the UFL Ambassador program continues to grow, our strongest recommendation for other educational practitioners centers on communication and connection. The most significant portion of time dedicated to the program involves promoting awareness among parents, students, school districts/personnel, community partners and other stakeholders regarding the program purpose and its benefits for students (Wilczenski \& Cook, 2009). We believe communication and connection are the two components that distinguish Ambassadors from other programs offered to youth and contribute to long-term commitment. Although these two components create additional challenges for practitioners, communication and connection are necessary to ensure quality and retention.

- Contact information updates - With long-term ongoing program engagement comes the consistent struggle to maintain correct contact information for students and parents. Our response has been to add an online registration form to the UFL website where parents can seamlessly update phone numbers, email addresses or mailing addresses. We use this information to update our program rosters.

- Embrace social media - Most adults and youth check social networks more frequently than email. In order to reach key stakeholders more efficiently we utilize Facebook, Instagram and Twitter to communicate with parents and students. Additionally, UFL utilizes the Remind101 (McCoy, 2016; Remind101, 2016) system to notify participants of upcoming events and activities via text message (preferred by many of our families who may not have access to email).

- Face-to-face registration opportunities - In addition to communication, connection is essential to maintaining long-term engagement. Even in a technology-driven society, people still need and value a personal, face-to-face connection. The program offers opportunities to renew UFL Ambassador registration at least twice a year at face-to-face events. We provide laptops at these events to allow parents to utilize the online registration form and familiarize them with the program website for future use.

Maintaining a personal connection with program stakeholders and ensuring staff members are always available for timely communication has become a foundational component of the UFL program. Without up-to-date contact information and ongoing awareness of upcoming opportunities, it would be challenging to engage over 400 registered UFL Ambassadors from numerous grades, schools, and communities. However, by incorporating multiple modes of one-on-one communication and connection, practitioners can improve the odds of student engagement and retention, as well as strengthen partnerships with parents, community organizations and school districts.

\section{Conclusion}

The information and suggestions presented in this application brief were developed based upon eight years of implementation, adaptation and evaluation within a youth leadership development program that currently impacts a diverse group of over 400 students regionally. Although continuously developing, the UFL Ambassador program has discovered methods to 
decrease, adapt to, and/or overcome many challenges inherent within long-term youth programming. With the understanding that long-term program evaluation is incredibly timeconsuming and requires sufficient resources, we present an in-depth description of our processes, strategies and personal reflections for practitioners in the field of youth development. While each program is unique, the various strategies utilized by the UFL Ambassador program can be adapted and integrated as an enhancement to existing programming to meet the needs of adolescents in various contexts. The promotion of civic contribution and long-term engagement is instrumental in order to develop positive, self-determined youth, and therefore should be considered and intentionally incorporated by educational practitioners.

\section{References}

Akos, P. (2006). Extracurricular participation and the transition to middle school. Research in Middle Level Education Online, 29(9), 1-9.

Crocetti, E., Jahromi, P., \& Meeus, W. (2012). Identity and civic engagement in adolescents. Journal of Adolescence, 35(3), 521-532. doi:10.1016/j.adolescence.2011.08.003

Deci, E. L., \& Ryan, R. M. (2000). The "what" and "why" of goal pursuits: Human needs and the self-determination of behavior. Psychological Inquiry, 11(4), 227-268.

Duerden, M. D. \& Witt, P. A. (2010). The impact of direct and indirect experiences on the development of environmental knowledge, attitudes, and behavior. Journal of Environmental Psychology, 30(4), 379-392. doi:10.1016/j.jenvp.2010.03.007

Edelman, A., Gill, P., Comerford, K., Larson, M., \& Hare, R. (2004). Youth Development \& Youth Leadership. A Background Paper. Institute for Educational Leadership. National Collaborative on Workforce and Disability for Youth, Washington, DC.

Fredricks, J. A. (2012). Extracurricular participation and academic outcomes: Testing the overscheduling hypothesis. Journal of Youth and Adolescents, 41(3), 295-306. doi:10.1007/s10964-011-9704-0

Gestsdóttir, S., \& Lerner, R. M. (2007). Intentional self-regulation and positive youth development in early adolescence: Findings from the 4-H study of positive youth development. Developmental Psychology, 43(2), 508. doi:10.1037/0012-1649.43.2.508

Gestsdottir, S., Urban, J. B., Bowers, E. P., Lerner, J. V., \& Lerner, R. M. (2011). Intentional self-regulation, ecological assets, and thriving in adolescence: A developmental systems model. In R. M. Lerner, J. V. Lerner, E. P. Bowers, S. Lewin-Bizan, S. Gestsdottir, \& J. B. Urban (Eds.). Thriving in childhood and adolescence: The role of self-regulation processes. New Directions for Child and Adolescent Development, 133, 61-76. doi:10.1002/cd.304 
Ginwright, S., Noguera, P., \& Cammarota, J. (Eds.). (2006). Beyond resistance! Youth activism and community change. New York, NY: Routledge.

Greiman, B. C., \& Addington, L. S. (2008). Youth leadership development self-efficacy: An exploratory study involving a new construct. Journal of Leadership Education, 7(1), 123.

Hancock, D., Dyk, P. H., \& Jones, K. (2012). Adolescent involvement in extracurricular activities: Influences on leadership skills. Journal of Leadership Education, 11(1), 84101.

Jelicic, H., Bobek, D. L., Phelps, E., Lerner, R. M., \& Lerner, J. V. (2007). Using positive youth development to predict contribution and risk behaviors in early adolescence: Findings from the first two waves of the 4-H Study of Positive Youth Development. International Journal of Behavioral Development, 31(3), 263-273. doi:10.1177/0165025407076439

Jones, K. R. (2009). Influences of youth leadership within a community-based context. Journal of Leadership Education, 7(3), 246-264.

Karcher, M. J. (2008). The cross-age mentoring program: A developmental intervention for promoting students' connectedness across grade levels. Professional School Counseling, 12(2), 137-143.

Kaye, C. B. (2010). The complete guide to service learning proven, practical ways to engage students in civic responsibility, academic curriculum, \& social action. Minneapolis, MN: Free Spirit Publishing.

Klau, M. (2006). Exploring youth leadership in theory and practice. New Directions for Youth Development, 109, 57-87. doi:10.1002/yd.155

Lauver, S. C., \& Little, P. M. D. (2005). Recruitment and retention strategies for out-of-schooltime programs. New Directions for Youth Development, Spring 2005(105), 71-89.

Lekies, K. S. (2009). Assessing participation in youth community action projects: Opportunities and barriers. Journal Community Development, 40(4), 346-358.

Lerner, R. M., Lerner, J. V., Almerigi, J. B., Theokas, C., Phelps, E., Gestsdottir, S., Naudeau, S., Jelicic, H., Alberts, A. E., Ma, L., Smith, L. M., Bobek, D. L., Richman-Raphael, D., Simpson, I., Christiansen, E. D., \& von Eye, A. (2005). Positive Youth Development, Participation in community youth development programs, and community contributions of fifth-grade adolescents: Findings from the first wave of the 4-H study of Positive Youth Development. The Journal of Early Adolescence, 25(1), 17-71.

Lerner, R. M., \& Lerner, J. V., and Colleagues. (2013). The positive development of youth: Comprehensive findings from the 4-H study of positive youth development. Report 
prepared by the Institute for Applied Research in Youth Development, Tufts University, Medford MA.

Li, Y., Bebiroglu, N., Phelps, E., Lerner, R. M., \& Lerner, J. V. (2008). Out-of-school time activity participation, school engagement and positive youth development: Findings from the 4-H study of positive youth development. Journal of Youth Development, 3(3), 8-21.

Ling, R. \& Bertel, T. (2013). Mobile communication culture among children and adolescents. In D. Lemish (Ed.), The Routledge international handbook of children, adolescents and media. (pp. 127-133). New York, NY: Routledge.

Matthews, T. L., Hempel, L. M., \& Howell, F. M. (2010). Gender and the transmission of civic engagement: Assessing the influences on youth civic activity. Sociological Inquiry, 80(3), 448-474. doi:10.1111/j.1475-682X.2010.00342.x

McCoy, K. (2016). What is Remind \& Why Should I Care? The Advantages of Utilizing a Onedirectional Text Message Application to Support Student Learning in Academia. Retrieved from https://www.editlib.org/p/171645/.

Melman, S., Little, S. G., \& Akin-Little, A. (2007). Adolescent overscheduling: The relationship between levels of participation in scheduled activities and self-reported clinical symptomology. The High School Journal, 90(3), 18-30.

Mueller, M. K., Phelps, E., Bowers, E. P., Agans, J. P., Urban, J. B., \& Lerner, R. M. (2011). Youth development program participation and intentional self-regulation skills: Contextual and individual bases of pathways to positive youth development. Journal of Adolescence, 34(6), 1115-1125. doi:10.1016/j.adolescence.2011.07.010

Murphy, S. E., \& Johnson, S. K. (2011). The benefits of a long-lens approach to leader development: Understanding the seeds of leadership. The Leadership Quarterly, 22(3), 459-470. doi:10.1016/j.leaqua.2011.04.004

National Charity League. (2016). The NCL Experience. Retrieved from https://www.nationalcharityleague.org/.

Overton, W. F. (2010). Life-span development: Concepts and issues. In R. M. Lerner(Ed.-inchief) \& W. F. Overton (Vol. Ed.), The Handbook of Life-Span Development: Vol. 1. Cognition, Biology, and Methods (pp. 1-29). Hoboken, NJ: Wiley.

Patrick, H., \& Williams, G. C. (2012). Self-determination theory: its application to health behavior and complementarity with motivational interviewing. International Journal of Behavioral Nutrition and Physical Activity, 9(1), 18-29. doi:10.1186/1479-5868-9-18

Polson, E. C., Kim, Y., Jang, S. J., Johnson, B. R. \& Smith, S. (2013). Being prepared and staying connected: Scouting's influence on social capital and community involvement. Social Science Quarterly, 94(3), 758-776. doi:10.1111/ssqu.12002 
Power, T. G., Ullrich-French, S. C., Steele, M. M., Daratha, K. B., \& Bindler, R, C. (2011).

Obesity, cardiovascular fitness, and physical active adolescents' motivations for activity: a self-determination theory approach. Psychology of Sport and Exercise, 12(6), 593-598. doi:10.1016/j.psychsport.2011.07.002

Qualtrics. (2015). Qualtrics [Computer software]. Utah: Provo.

Remind101. (2016). Remind101. Retrieved from https://www.remind.com/.

Richards-Schuster, K. \& Dobbie, D. (2011). Tagging walls and planting seeds: Creating spaces for youth civic action. Journal of Community Practice, 19(3), 234-251.

doi:10.1080/10705422.2011.595283

Riggs, N. R., Bohnert, A. M., Guzman, M. D., \& Davidson, D. (2010). Examining the potential of community-based after-school programs for Latino youth. American Journal of Community Psychology, 45(3), 417-429. doi:10.1007/s10464-010-9313-1

Roberts, C. (2008). Developing future leaders: The role of reflection in the classroom. Journal of Leadership Education, 7(1), 116-130.

Root, S., Callahan, J., Billig, S. H. (2005). The relationship between the quality indicators of service-learning and student outcomes testing professional wisdom. In S. Root, J. Callahan \& S. H. Billig (Eds.), Improving service learning practice research on models to enhance impacts (pp. 97-118). Greenwich, CT: Information Age Publishing.

Schmid, K. L., Phelps, E., Kiely, M. K., Napolitano, C. M., Boyd, M. J., \& Lerner, R. M. (2011). The role of adolescents' hopeful futures in predicting positive and negative developmental trajectories: Findings from the 4-H Study of Positive YouthDevelopment. The Journal of Positive Psychology, 6(1), 45-56.

Schultheiss, D. E. P. \& Pennington, D. (2009). Problems with and needs for interdisciplinary interactions in vocational guidance. The Career Development Quarterly, 57(4), 319-326.

Sheffield, E. C. (2011). Strong community service learning: Philosophical perspectives. New York, NY: Peter Lang Publishing Inc.

Sherrod, L. (2016). Civic engagement as an expression of Positive Youth Development. Retrieved from https://www.corwin.com/sites/default/files/upmbinaries/15175_4967_Silbereisen_Ch03.pdf.

Sherrod, L. R., Flanagan, C., \& Youniss, J. (2002). Dimensions of citizenship and opportunities for youth development: The what, why, when, where, and who of citizenship development. Applied Developmental Science, 6(4), 264-272. 
Simmons, L. \& Harding, S. (2011). Engaging youth in community practice-An imperative for the future. Journal of Community Practice, 19(3), 229-233. doi:10.1080/10705422.2011.595361

Strom, P. S., Strom, R. D., \& Sindel-Arrington, T. (2016). Adolescent views of time management: Rethinking the school day in junior high school. American Secondary Education, 44(3), 38-55.

Theokas, C., \& Lerner, R. M. (2006). Observed ecological assets in families, schools, and neighborhoods: Conceptualization, measurement, and relations with positive and negative developmental outcomes. Applied Developmental Science, 10(2), 61-74. doi:10.1207/s1532480xads1002_2

Thogersen-Ntoumani, C., Ntoumanis, N., \& Nikitaras, N. (2010). Unhealthy weight control behaviors in adolescent girls: a process model based on self-determination theory. Psychology and Health, 25(5), 535-550. doi:10.1080/08870440902783628

United Future Leaders. (2016). United Future Leaders. Retrieved from http://www.depts.ttu.edu/hs/ufl/index.php.

Webster, N. S., Bruce, J. A., \& Hoover, T. S. (2006). Understanding the perceptions of service learning with teen leaders. Journal of Leadership Education, 5(1), 26-38.

Wilczenski, F. \& Cook, A. (2009). How service learning addresses the mental health needs of students in urban schools. Journal of School Counseling, 7(25), 1-20.

\section{Author Biographies}

Kayla Sherman [kayla.thomas@ttu.edu] serves as Assistant Director of United Future Leaders (UFL) at Texas Tech University, Center for Adolescent Resiliency. She holds a M.S.in Family and Consumer Sciences Education and a dual-degree B.A. (communication studies and public relations) from TTU. Kayla is also a certified educator of secondary speech.

Gloria Gonzales [gloria.gonzales@ttu.edu] is the Assistant Director at Texas Tech University Center for Adolescent Resiliency and Director of the United Future Leaders program. She received her Bachelor of Science in Education from Lubbock Christian University and Masters of Counseling in Education from Sul Ross State University.

Dr. Sara L. Dodd [sara.dodd@ttu.edu] is an Associate Professor in the College of Human Sciences at Texas Tech University and the Director of the Center for Adolescent Resiliency. She holds a BA degree in government/political science, a MBA in management, and a PhD in Family \& Consumer Sciences Education.

Dr. Erin Kostina-Ritchey [erin.ritchey@ttu.edu] is a researcher at Texas Tech University Center for Adolescent Resiliency and a certified Family Life Educator. She received an 
Interdisciplinary Masters of Arts in International Community Development \& Public Policy, Masters of Education in Curriculum \& Instruction and a Ph.D. in Human Development \& Family Studies. 